\title{
Belgelerle İstanbul Üniversitesi Edebiyat Fakültesinde Mülteci Bilim Adamlart
}

Sevtap İshakoğlu-Kadığlu, Gaye Şahinbaş Erginöz, İstanbul Üniversitesi, 2017, 387 Sayfa ISBN 978-6-0507-0629-1

Nedret ÖZTOKAT KILIÇERI' ${ }^{10}$

Istanbul University, Faculty of Letters, Western Languages and Literatures, French Language and Literature, Istanbul, Turkey

ORCID: N.Ö.K. 0000-0003-3445-1275

\section{Corresponding author:}

Nedret ÖZTOKAT KILıÇERI, İstanbul Üniversitesi, Edebiyat Fakültesi, Batı Dilleri ve Edebiyatları Bölümü, Fransız Dili ve Edebiyatı Anabilim Dalı, Ordu Cad. No: 6 B Blok IV. Kat Oda: 08, 34134, Laleli, İstanbul, Türkiye

E-mail: nedretoztokat@yahoo.fr

Submitted: 04.04.2019. Accepted: 09.04.2019

Citation: Oztokat-Kiliceri, N. (2019). Belgelerle İstanbul Üniversitesi Edebiyat Fakültesinde Mülteci Bilim Adamları [S. İshakoğlu-Kadığlu ve G. Şahinbaş Erginöz tarafından yayına hazırlanan Belgelerle İstanbul Üniversitesi Edebiyat Fakültesinde Mülteci Bilim Adamları başlıklı kitabın değerlendirmesi]. Litera, 29(1), 113-117. https://doi.org/10.26650/LITERA2019-0020

Türkiye'nin ilk üniversitesi İstanbul Üniversitesi'nin modern bir bilim kurumu olarak yapılanması Cumhuriyet'in en önemli tasarılarından biridir. Türkiye Cumhuriyeti'nin kuruluşunu izleyen ilk on yılda gerçekleştirilen kökten yenilenmelerden biri olan yükseköğretim reformu 1933 yılında "Üniversite Reformu" adıyla tarihe geçmiştir. Böylece Darülfünun'dan', Batılı anlamda, evrensel bilgiye açık, fakültelerinde ücretsiz eğitim veren ve bilim adamlarını bir araya getiren laik bir

1 Darülfünun'un Medreseden modern üniversiteye geçişte önemli bir rol oynadığı sıklıkla yinelenmiştir. Özellikle on sekizinci yüzyıl ve ardından Tanzimat Fermanı́nın ilanıyla Batılı tarzda eğitim ve bilim anlayışını örnek alan yenilikçi zihniyetin ciddi bir eğitim reformundan yana olduğu sadece meslek alanında değil, bilim ve eğitimde de çağı yakalayan bir eğitim amaçladıkları kaynaklarda bulunmaktadır. 
kurum olan "Üniversite"'ye geçildi (Üniversite sözcüğünü anımsatalım: Kökenbilimsel olarak, hem "evren" (univers) hem de "topluluk, öğrenci ve öğretim üyesi topluluğu" (corporation) anlamlarını içermektedir).

Bu reformla Batıda XI. yüzyıldan itibaren ortaya çıkmaya başlayan ve evrensel bilgilere dayalı bir kurum olma özelliğiyle "üniversite", yapısı, işleyişi ve işlevleriyle örnek alındı; ülke gençlerinin yükseköğrenim görecekleri yeni ve çağdaş bir bilim kurumu olarak görüldü. Avrupa modelini benimseyen bu reform ülkemizde bugüne dek oluşturulmuş eğitim/öğretim politikaları arasında en geniş alanlı, en tutarlı ve toplumsal konsensüsle en sıkı bağı oluşturanıdır kuşkusuz. Ülkenin gelişmesinde üniversiteye ve bilime biçilen rolün ortak değer ve ilkelerle belki de en güçlü bir biçimde destek bulduğu bir harekettir. Çağdaş bilimsel düzeyi yakalamayı amaçlamış, yeni bir yükseköğretim ufku yaratacak, ülkeyi ileriye taşıyacak bu girişimi gerçekleştirmede devlet politikaları son derece somut yaklaşımlar izlenmiştir. 1930'larda özellikle Almanya'yı kasıp kavuran Nazi iktidarının yol açtığı bilimsel göç genç cumhuriyetin hedefindeki reformun gerçekleşmesinde önemli rol oynamıştır. Prof. Şârâ Sayın'ın tanıklığıyla, Alman mülteci profesörlerin Türkiye'ye çağrılmalarında etkin görevi Cenevre Üniversitesi profesörlerinden Albert Malche üstlenmiştir. 1932 yılında "Islahat Müşaviri" sıfatıyla Ankara'ya davet edilen Malche yabancı profesörlerle irtibat kurma ve görevlendirilmeleri konusunda yetkilendirilmiştir (Ozil-Öztokat, 2009, s. 22). Yine bu konuyla ilgilenen bir başka araştırmacı Kader Konuk üniversite reformunun kültürel ve siyasi reformlardan ayrı tutulmayacağını, Milli Eğitim bakanları Reşit Galip ver Hasan Âli Yücel'in de aktörleri arasında bulunduğu bu geniş menzilli hareketin aslında “Osmanlı İmparatorluğu'nun geçen iki yüzyıldaki kültürel, iktisadi, siyasi ve askeri dönüşümüne damgasını vuran Batııılaşma reformlarının kapsamını daha da genişletmek" anlamı taşıdığına dikkat çeker (Konuk, 2011, s. 19).

Türkiye'nin ilk Edebiyat Fakültesi olan İstanbul Üniversitesi Edebiyat Fakültesi 1933'te gerçekleşen bu reformla kurulmuştur. Prof. Dr. Sevtap İshakoğlu Kadıoğlu ve Doç. Dr. Gaye Şahinbaş Erginöz'ün birlikte hazırladıkları Belgelerle Istanbul Üniversitesi Edebiyat Fakültesinde Mülteci Bilim Adamları başlıklı dev çalışma İstanbul Üniversitesi tarafından geçtiğimiz günlerde yayımlandı. Ülkemizin bilim tarihi alanına önemli katkı sunan yapıt, aynı zamanda "ortak bellek", "toplumsal hafıza", "geleneğin yol göstericiliği", "tarihe kayıt düşme" gibi son yıllarda dilimizden düşmez hale gelen kavramları daha ilk okumada akla getiriyor. 
Prof. Dr. Sevtap Kadıoğlu ve Doç. Dr. Gaye Erginöz, 1933 reformu çerçevesinde Edebiyat Fakültesi'nin tarihçesini ele aldıkları bu araştırmada, artsüremli/tarihsel bir yol izleyerek, Fakülte Özlük Arşivinden titizlikle derledikleri belgelerle Edebiyat Fakültesi'nde kimi kürsülerin kurulmasında, müfredatların hazırlanmasında, derslerin yürütülmesinde etkin görev almış Batı'dan ülkemize göçen bilim insanlarının kapsamlı bir dökümünü sunuyorlar. Yazarlar nesnel, betimsel ve tümü kapsayıcı bir yaklaşımla, İstanbul'da çalışmış 24 öğretim üyesinin yaşamöykülerini, fakültede verdikleri dersleri ve yayınlarını kapsayan bilgileri bir araya getirmişler.

Başta Almanya, ardından da Avusturya gibi ülkelerde Nazizmin yükselişi sırasında çoğu kürsülerinden uzaklaştırılmak yoluyla işsiz kalan öğretim üyeleri, bu değerli çalışmada, yüzleri ve yapıtlarıyla bugüne ulaşıyor. Vesikalık bir fotoğrafın eşlik ettiği bir kimlik kaydı formatına uygun özlü bir curriculum vitae'nin yer aldığı birinci sayfanın ardından ilgili kişinin yaşamöyküsüne ulaşıyorsunuz. Bu metni hocanın fakültede vermiş olduğu derslerin ve yayınlarının listesi izliyor. Bu üç bölümü izleyen ve ikametgâh, beyanname, atama/ görevlendirme yazıları, vekâletname gibi resmi belgelerin yanı sıra, konferans duyuruları, aile fotoğrafları gibi özgün belgeler yapıtın görsel belgelerini okura sunuyor. Cumhuriyet'in eğitim tarihine de tanıklık eden bu sayfaları yine her öğretim üyesiyle ilgili ulaşılabilecek kapsamlı bir kaynakça izliyor.

Kitapta kaynakların özgün biçimleri ve çevirilerinin tarihleriyle verilmiş olması, bu profesörlerin bilinmeyen yaşamöykülerini ve bilim hayatımıza katkılarını bir araya getirmesi bugüne dek yapılmamış bilimsel bir çalışmayı örnekliyor. Yirmi dört bilim insanının İstanbul Üniversitesi'nde çalıştığı sürelere, bağlı bulundukları kürsülere ait bilgilerin yer aldığı tablo ise (Kadıoğlu-Erginöz, 2007, s. 28). Edebiyat Fakültesi tarihçesini özetliyor. Bu açılardan bakınca, elimizdeki yapıt sadece yakın dönem bilim tarihimizi değil, Cumhuriyet'in erken döneminde toplumsal ve kültürel tarihimizi, aynı zamanda da İstanbul Üniversitesi ve Edebiyat Fakültesinin kuruluş ve gelişimini tanıtan önemli bir belge niteliği kazanıyor.

Kadıoğlu ve Erginöz'ün saptadığı gibi “Edebiyat Fakültesinde görev alan mülteci öğretim üyelerinden üçü Felsefe kürsüsünde, biri Psikoloji-Pedagoji Enstitüsü'nde, biri Beşeri İktisadi Coğrafya kürsüsünde, ikisi Eskiçağ Tarihi kürsüsünde, biri İstanbul Üniversitesi Kütüphanesi'nde, biri de Türkiyat Enstitüsü'nde ders vermişler (...)" gelenlerin büyük kısmını filologlar oluşturmuş̧tur (Kadıoğlu-Erginöz, 2007, s. 367). 
Bu öğretim elemanlarının Türkiye'ye geliş hikâyeleri kadar, burada bulundukları süre içinde verdikleri hizmetler de ayrıntılı biçimde kitapta yer almaktadır. Bunlar yükseköğrenimlerini ülkelerinin önde gelen üniversitelerinde tamamlamış, ancak Yahudi kökenleri nedeniyle Nazi yönetimince gözaltına alınmış, tutuklanmış, sürgüne zorlanmıştır. Türkiye'ye gelmeleri tam bir maceradır. Aralarında Nazi toplama kampı Dachau'ya gönderilerek, Türk bilim adamlarının çabaları sonucu Türkiye'ye gelen Karl Süssheim'ı anabiliriz (Kadıoğlu-Erginöz, 2007, s. 305).

Buraya geldiklerinde çoğu Alman, Avusturya ve bazı Türk Liselerinde ders vererek hayatlarını sürdürmüş, üniversitede çalışmaya başladıklarında eşleri ve çocuklarını yanlarına getirtebilmişlerdir. Göreceli olarak güvenli ve huzurlu oldukları ve asıl işleri olan bilimle geçen bu dönem İkinci Dünya Savaşı'yla gölgelenmiştir. Almanya ile müttefik olmamız nedeniyle bazıları ülkelerine çağrılacak, dönmemeleri halinde ise İstanbul'dan uzaklaştırılacaklardır (1944-45 yıllarında Eva Buck Yozgat'ta; Traugott Fuchs, Hans Marchand Çorum'da, Heinz Anstock, Kurt Laqueur Kırşehir'de enterne edilmiştir).

Bu göçmenler 1950'lerden sonra ülkelerine döndükten sonra da Türkiye'ye gelmişler, özellikle İstanbul Üniversitesi'nde konferans, seminer vererek eski öğrencileri ve meslekdaşlarıyla bir araya gelerek, bu toprakla bağlarını sürdürmüşlerdir. Aralarından bazıları İstanbul'da vefat etmiş ve burada toprağa verilmiştir. Üniversiteye verdikleri hizmet, üstlendikleri bilimsel, akademik ve idari görevlerdeki titizlikleri ve üretkenlikleriyle "Ordinaryus Profesör" derecesine yükseltilenler olduğu gibi (Prof. Walther Kranz) (Kadıoğlu-Erginöz, 2007, s. 202); akademik dereceye sahip olmayanları üniversitelerimiz "Onur Doktorası" (Traugott Fuchs) (Kadıoğlu-Erginöz, 2007, s. 155) ya da "Fahri Profesörlük" unvanıyla (Eva Buck) (Kadıoğlu-Erginöz, 2007, s. 113) onurlandırmıştır. Türk dili ve tarihine katkılarından dolayı madalya ve plaketlerle onurlandırılanlar (Prof. Andreas Tietze) (KadıoğluErginöz, 2007, s. 329), ya da gittikleri üniversitelerden Türkiye'ye konuk öğretim üyesi davetli olarak çağrılan ve ikinci kez görev alanları da (Prof. Dr. Hans Marchand) (Kadıoğlu-Erginöz, 2007, s. 230) unutmamak gerekir.

Türkiye'ye göç eden Batılı bilim insanlarının izini süren Prof. Dr. Kadıoğlu ve Doç. Dr. Erginöz'ün bu kapsamlı yapıtın sonuç kısmında belirttikleri gibi, bu profesörler Edebiyat Fakültesi'nin özelikle Felsefe, sosyoloji, Psikoloji Eski Çağ tarihi, Kütüphanecilik ve Batı Filolojileri ve Türkoloji alanlarında önemli hizmetlerde 
bulunmuşlardır (Kadıoğlu-Erginöz, 2007, s. 363-370). Öncelikle kürsü dergilerinin bilimsel yayın olarak kurulması ve sürdürülmesi; psikoloji gibi alanlarda deneysel çalışmalar için laboratuvarlar kurulması (Türkiye'nin ilk deneysel laboratuvarı 1937 yılında Edebiyat Fakültesi'nde kurulmuştur); arkeoloji kazılarında tasnif, kataloglama ve rehberlerin hazırlanmasına öncülük etme; Türkiye nümizmatiğinin geniş bir bibliyografyasını oluşturma; Türkiye'deki kütüphanecilik sisteminin kurulması; folklor, etnografya, dil, tarih çalışmalarının gelişmesiyle yurt dışında Türkoloji'nin başlatılması; Türkçenin etimolojik sözlüğünün hazırlanması; dil çalışmalarında yöntemsel yaklaşımların saptanmasıyla dilbilimin bir bilim dalı olarak tanınması; yabancı dil eğitiminin çağdaş yaklaşımlarla buluşması gibi girişimler bilimsel araştırmalarımıza yeni bir soluk getirmiştir.

Kadıoğlu ve Erginöz'ün geniş ve titiz çalışması, Türkiye'ye göç ederek kurdukları yeni yaşantılarında tıpkı kendi ülkelerinde olduğu gibi aynı disiplin, ciddiyet ve tutkuyla kendilerini bilime adamış insanların anısını yaşatan bir tanıklık; ülkemizin sürgün misafirleri bu göçmen ruhlara saygıyla sunulan bir selam; bilimin çağdaş teknolojilerle sürekli ve hızla gelişmesine karşın, beslendiği kaynağın ne kadar kıymetli olduğunu anlatan bir bellek-yapıt.

\section{Kaynakça}

Kadıoğlu, S. \& Şahinbaş Erginöz, G. (2017). Belgelerle İstanbul Üniversitesi Edebiyat Fakültesinde Mülteci Bilim Adamları. İstanbul, TR: İstanbul Üniversitesi Yayını.

Konuk, K. (2011). Doğu Batı Mimesis: Auerbach Türkiye'de. İstanbul, TR: Metis.

Ozil, Ş. \& Öztokat, N. (2009). 1933'ten 2008'e İstanbul Üniversitesi Batı Filolojilerinin 75. Yılı. İstanbul, TR: İstanbul Üniversitesi Yayınları. 
